\title{
Recommendations for the initial management of multisystem inflammatory syndrome temporally related to COVID-19, in children and adolescents
}

Hospital "Prof. Dr. Juan P. Garrahan," Autonomous City of Buenos Aires, Argentina. Sociedad Latino Argina. Sociedad Latinoamericana Emergencia Pediátrica.

Emergency Department, Hospital "Prof. Dr. Juan P. Garrahan," Autonomous City of Buenos Aires, Argentina. Sociedad Latinoamericana de Emergencia Pediátrica.

c. Institute of Science and Medical Innovation, Universidad del Desarrollo and Hospital El Carmen de Maipú, Santiago, Chile. Red Colaborativa Pediátrica de Latinoamérica (LARed Network).

d. Pediatric Intensive Care Unit, Hospital General de Medellín. Universidad de Antioquía, Colombia. Red Colaborativa Pediátrica de Latinoamérica (LARed Network).

e. Specialized Pediatric Intensive Care (SPIC), Casa de Galicia, Montevideo, Uruguay. Red Colaborativa Pediátrica de Latinoamérica (LARed

de Latinoan
Network).

f. Universidad Nacional de Colombia and Health Science University Foundation (Fundación Universitaria de Ciencias de la Salud), Bogotá, Colombia. Red Colaborativa Pediátrica de Latinoamérica (LARed Network).

g. Department of Pediatrics and Critical Care, Universidad de la Sabana. Pediatric Heart Health Foundation (Fundación Cardioinfantil), Institute of Cardiology, Bogotá, Colombia. Red Colaborativa Pediátric de Latinoamérica (LARed Network).

h. Pediatric Intensive Care Unit, Police Medical Complex "Churruca Visca," Autonomous City of Buenos Aires, Argentina Shock Committee, Sociedad Argentina de Terapia Intensiva. Intensive Care Department, Hospital Regional de Reconquista, Santa Fe Argentina. Red Colaborativa Pediátrica de Latinoamérica (LARed Network). Universidad Católica de Santa Fe.

j. Pediatric Intensive Care Unit, Hospital Doctor Guillermo Rawson, San Juan, Argentina. Shock Committee, Sociedad Argentina de Terapia Intensiva.

k. School of Medicine,

Universidad Nacional

del Nordeste, Corrientes, del Nordeste, Corrientes,
Argentina. Red Colaborativa Pediátrica de Latinoamérica (LARed Network).

E-mail address:

Guillermo Kohn-Loncarica, M.D.:

gkohnloncarica@gmail.com

Funding: None.

Conflict of interest: None.

Received: 7-15-2020 Accepted: 7-22-2020

\author{
Guillermo Kohn-Loncarica, M.D. ${ }^{a}$, Ana Fustiñana, M.D. ${ }^{b}$, Franco Díaz-Rubio, M.D. ${ }^{c}$, \\ Juan C. Jaramillo-Bustamante, M.D. ${ }^{d}$, Sebastián González-Dambrauskas, M.D. ${ }^{e}$, \\ Pablo Vásquez-Hoyos, M.D.f, Jaime Fernández-Sarmiento, M.D. ${ }^{g}$, Gustavo González, M.D. ${ }^{h}$, \\ Alejandro Mansur, M.D. ${ }^{i}$, Javier Ponce, M.D. ${ }^{j}$ and Roberto Jabornisky, M.D. ${ }^{k}$
}

\begin{abstract}
Multisysteminflammatory syndrometemporally related to COVID-19 in children and adolescents is a clinical presentation of SARS-CoV-2 infection. It shares some features with Kawasaki disease, toxic shock, sepsis, macrophage activation syndrome, and myocarditis. Few publications have addressed its initial management, which is similar to that proposed for septic shock. This review analyzes such approach based on the characteristics typical of multisystem inflammatory syndrome related to COVID-19 in accordance with the paradigm of an "institutional practice guideline" and suggests therapeutic approach strategies, including early detection, stabilization, referral, specific treatment, and process analysis.

Key words: patient care bundles, multisystem inflammatory syndrome, COVID-19, sepsis, SARS$\mathrm{CoV}-2$.
\end{abstract}

http: / / dx.doi.org/10.5546/ aap.2020.eng.e514

To cite: Kohn-Loncarica G, Fustiñana A, Díaz-Rubio F, Jaramillo-Bustamante JC, et al. Recommendations for the initial management of multisystem inflammatory syndrome temporally related to COVID-19, in children and adolescents. Arch Argent Pediatr 2020; 118(6):e514-e526.

\section{INTRODUCTION}

Coronavirus disease (COVID-19) was declared a pandemic in $2020 .{ }^{1}$ To date, its impact on pediatrics has been small in terms of both severity and frequency, and different clinical presentations have been reported..$^{2-9}$

Cases have been described since May in previously healthy European children, and reports have been made of the onset of a condition associated with COVID-19 characterized by a hyperinflammatory response..$^{10-14}$ Such condition is called multisystem inflammatory syndrome in children (MIS-C) temporally related to COVID-19 and shares clinical characteristics with Kawasaki disease (KD), toxic shock syndrome (TSS), sepsis, macrophage activation syndrome, and hemophagocytic lymphohistiocytosis; and it may also occur in association with myocarditisinduced cardiogenic shock. ${ }^{15-22}$

Currently, MIS-C is an uncommon disease overlapping with other conditions; therefore, a high clinical suspicion is required for a timely identification. ${ }^{10-22}$ Like sepsis, MIS-C presents with an inadequate immune response to infection leading to different types of organ dysfunction and is life-threatening. ${ }^{23}$ In the case of both sepsis and MIS-C, a high diagnostic suspicion is critical and its management may require rapid and timely advanced life support interventions in an adequate setting. MIS-C prognosis is currently good, and mortality has been reported to be low, although a late diagnosis may worsen the outcomes. ${ }^{10-22}$

Although the Surviving Sepsis Campaign (SSC) has recently issued updated clinical practice guidelines (CPGs) for hemodynamic support in septic shock (SSh) in pediatrics, few articles have addressed the initial management of MIS-C. ${ }^{5,24-27}$ Several governments, like the Argentine government, have introduced MIS-C as a diagnostic criterion for COVID-19, and this calls for the need to provide care strategies to health care providers. ${ }^{5,28}$ 
In 2019, Archivos Argentinos de Pediatría published updated initial management guidelines for SSh in children and proposed "bundles of measures" to approach it. ${ }^{29,30}$ It is worth noting that developing institutional practice guidelines (IPGs) agreed upon by the entire health care team (emergency department, hospitalization ward, critical care unit, pharmacy, laboratory, hemotherapy, pre-hospital practitioners, and primary care physicians, among others) is critical to establish a time-sensitive diagnosis and management where the setting and a joint effort are key. ${ }^{29}$

Our objective is to propose, based on the information available to date, recommendations for the development of institutional bundles of measures (early detection, treatment, stabilization, referral, and process analysis) for the initial management of MIS-C aimed at improving the quality of care provided to children with this condition.

\section{BUNDLES OF MEASURES}

"Patient care bundles" are diagnostic/ therapeutic actions to better address and manage medical processes. ${ }^{31}$ They include practices based on different levels of evidence in relation to a care process that, when developed collectively, result in a synergy that improves care (Figure 1). Five care bundles were proposed: early detection, immediate and time-sensitive resuscitation, stabilization, timely referral with the intervention of suitable health care providers in case of inadequate treatment response, and process

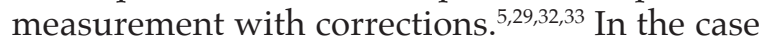
of MIS-C, pediatricians specialized in Emergency Care, Critical Care, Internal Medicine, Infectious Diseases, Immunology, and Rheumatology should be involved. ${ }^{5,29}$

A goal-directed therapy (GDT) protocol should be implemented in MIS-C based on the evidence of its use in pediatric SSh, in spite of the criticism around it in adult care. ${ }^{34-39} \mathrm{~A}$ strict, uniform implementation in all patients and across all institutions does not always result in similar outcomes, probably because it does not involve those who make decisions in close patient care. ${ }^{40-43}$ Therefore, it is essential to develop IPGs in accordance with the resources available at each site and to get the entire health care team involved..$^{29}$

FIGURE 1. Bundles of measures for multisystem inflammatory syndrome temporally related to COVID-19 and recognition, resuscitation, stabilization, referral, and process measurement elements (adapted by the authors from Kohn Loncarica et al. ${ }^{30}$

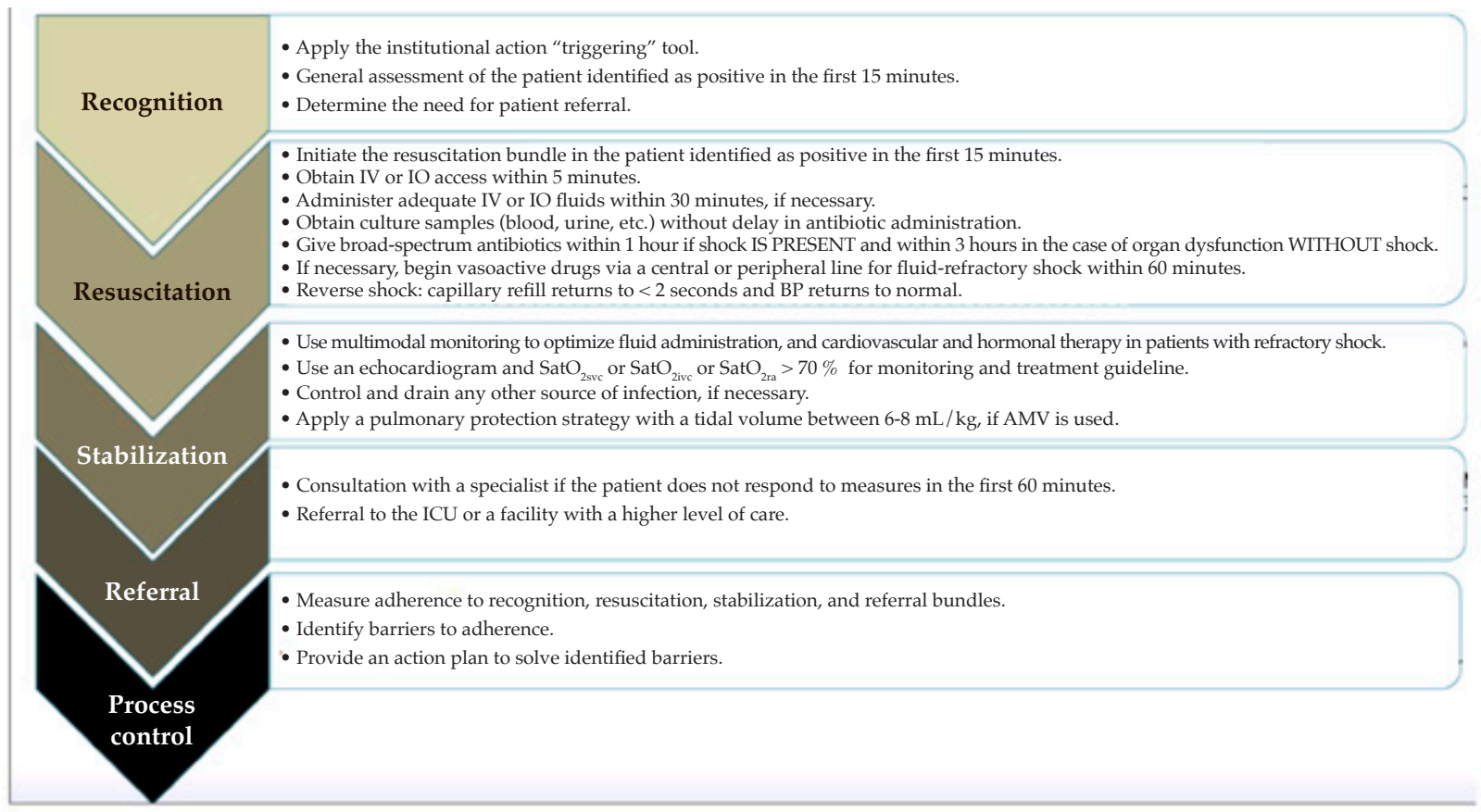

IV: intravenous; IO: intraosseous; $\mathrm{BP}$ : blood pressure; $\mathrm{SatO}_{2 \mathrm{svc}}$ : oxygen saturation in the superior vena cava; $\mathrm{SatO}_{2 \mathrm{ivc}}$ : oxygen saturation in the inferior vena cava; $\mathrm{SatO}_{2 \mathrm{ra}}$ : oxygen saturation in the right atrium;

AMV: assisted mechanical ventilation. 


\section{RECOGNITION BUNDLE}

An early MIS-C detection is critical for an optimal and time-sensitive treatment; therefore, it is essential to bear clinical criteria in mind. MIS-C is characterized by an ongoing, progressive inflammatory response. It has been referred to with different terms, such as pediatric inflammatory multisystem syndrome temporally associated with COVID-19 (PIMS-TC), and MIS-C, a more rigorous and specific term that we used in this review. ${ }^{15,16,44}$ As in the case of other evolving, dynamic entities with inaccurate limits, the use of strict clinical criteria may hinder the initial recognition. . $^{45-47}$

The definition by the World Health Organization (WHO) encompasses children and adolescents aged 0-19 years with persistent fever ( $>3$ days) in association with clinical manifestations in two or more systems (mucocutaneous, circulatory, cardiac, hematological, and gastrointestinal); elevated markers of inflammation with no other obvious microbial cause; and evidence of COVID-19 (as per reverse transcription polymerase chain reaction [rtPCR], antigen test or positive serology) or contact with COVID-19 patients. In some cases, clinical suspicion may be the only valid tool to assume it is MIS-C. ${ }^{16}$

Recent publications have described the clinical characteristics of MIS-C (please read these for a more comprehensive report) (Table 1). ${ }^{5,10-22}$ Cases have been reported across all pediatric age groups and all ethnic origins, in spite of initial reports of a higher incidence among African-Americans and Hispanics. ${ }^{5,10-22}$ Most reports point out that MIS-C is prevalent between 6 and 12 years old, although the Critical Coronavirus and Kids Epidemiology (CAKE) study reported that patients with

TABLE 1. Age, clinical manifestations, and course of multisystem inflammatory syndrome temporally related to COVID-19 according to different publications ${ }^{13-15,20,21}$

\begin{tabular}{|c|c|c|c|c|c|c|c|}
\hline & & \multicolumn{6}{|c|}{ Publications (countries where patients were included) } \\
\hline & & $\begin{array}{l}\text { Belhadjer et al. } \\
\text { (France and } \\
\text { Switzerland) } \\
n=35\end{array}$ & $\begin{array}{l}\begin{array}{c}\text { Verdoni } \\
\text { et al. } \\
\text { (italy) }\end{array} \\
\mathrm{n}=10\end{array}$ & $\begin{array}{c}\text { González- } \\
\text { Dambrauskas et al. } \\
\text { (Italy, Spain, Chile, } \\
\text { Colombia, USA)" } \\
\qquad \mathrm{n}=17\end{array}$ & $\begin{array}{l}\text { Duffort et al. (USA) } \\
\qquad n=99\end{array}$ & $\begin{array}{c}\text { Feldstein et } \\
\text { al. (USA) } \\
\mathrm{n}=186\end{array}$ & $\begin{array}{c}\text { Davies et al. } \\
\text { (United } \\
\text { Kingdom) }\end{array}$ \\
\hline \multirow{9}{*}{ 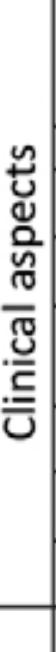 } & Median age, in years & 10 & 7.5 & 4 & $\begin{array}{c}0-5 \text { y.o. }=31 \text { p. } \\
6-12 \text { y.o. }=42 \text { p. } \\
13-20 \text { y.o. }=26 \text { p. }\end{array}$ & 8.3 & 11 \\
\hline & Fever (\%) & 100 & 100 & 76 & 100 & 100 & 100 \\
\hline & Conjunctival injection (\%) & NR & 20 & NR & 56 & 55 & 29 \\
\hline & Skin involvement (\%) & 57 & 80 & 0 & 62 & 74 & 45 \\
\hline & $\begin{array}{l}\text { Gastrointestinal involvement } \\
\text { (\%) }\end{array}$ & 83 & 60 & 35 & 79 & 92 & 90 \\
\hline & Cardiac involvement (\%) & 80 & 60 & 24 & 53 & 80 & 87 \\
\hline & Respiratory involvement (\%) & 65 & NR & 35 & 40 & 70 & 85 \\
\hline & Neurological involvement (\%) & 31 & 40 & 17 & 30 & 6 & NR \\
\hline & Deceased $(\%)$ & 0 & 0 & 6 & 2 & 2 & 2.6 \\
\hline
\end{tabular}

p. = the number of patients in the group is indicated because there is no description of the group's median value.

NR: no reference in the report.

The percentage $(\%)$ corresponds to the clinical presentation of each sign and symptom in each series.

${ }^{a}$ Data from patients with COVID-19 at the PICU; it is the only publication to date that includes patients from Latin America.

${ }^{\mathrm{b}}$ Median age was not reported, only distribution by age group. 
FIGURE 2. Clinical and laboratory outcome measures in relation to age and clinical presentations

\section{0-5 years old}

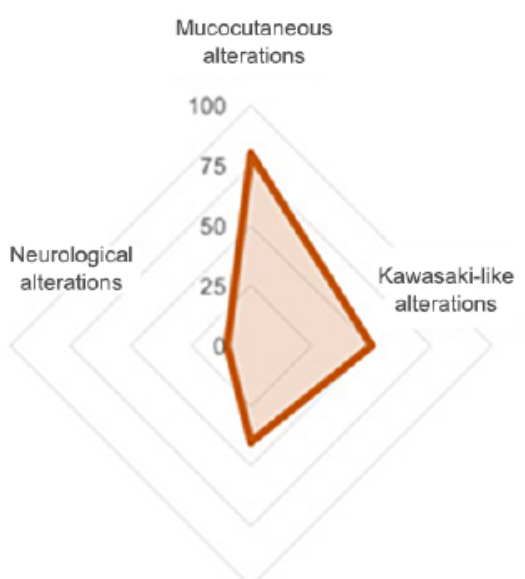

Myocarditis
6-12 years old

Mucocutaneous

alterations

100

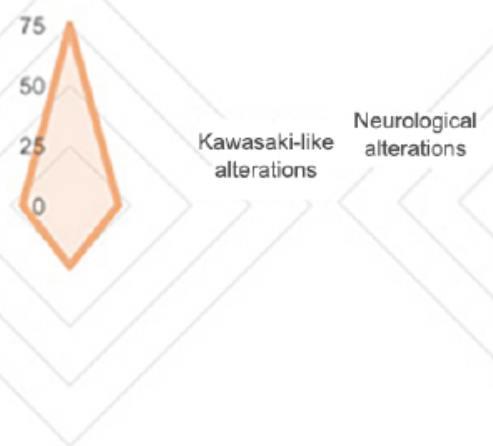

Myocarditis
13-20 years old

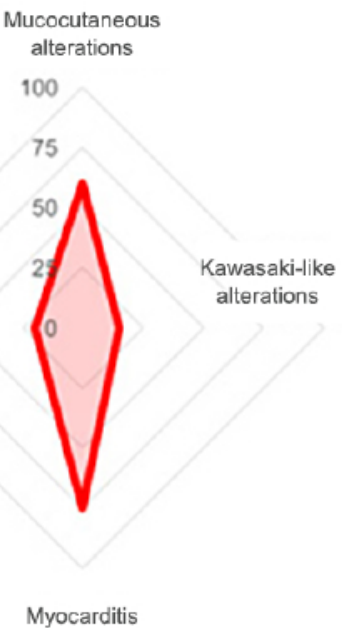

Kawasaki-like MIS-C

MIS-C (per se)

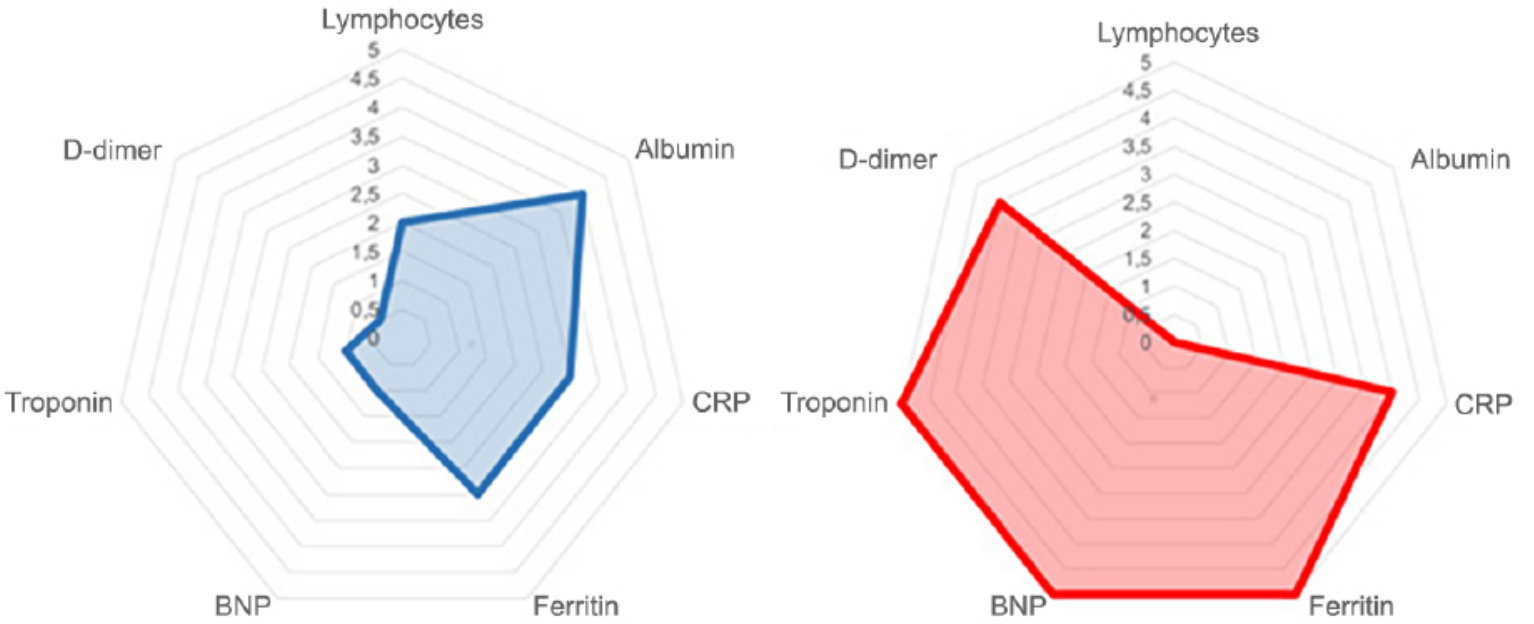

Radar chart based on Franco Díaz's personal observations in Chile. Each radius size accounts for the value of each outcome measure.

A. Clinical manifestations in patients aged 0-5 years. Mucocutaneous manifestations and Kawasaki disease or incomplete Kawasaki disease outcome measures prevail.

B. Clinical manifestations in patients aged 6-12 years. Skin manifestations still prevail, although neurological manifestations and myocarditis start to be more common than in A.

C. Clinical manifestations in patients aged 13-20 years. Myocarditis and neurological manifestations prevail, unlike mucocutaneous manifestations.

D. Biochemical outcome measures in SARS-CoV-2 positive patients and Kawasaki-like clinical presentation, in a scale of 1 (less likely to occur) to 5 (more likely to occur). Elevated CRP and ferritin, with albumin and lymphocyte alterations, prevail.

E. Biochemical outcome measures in SARS-CoV-2 positive patients and MIS-C clinical presentation, in a scale of 1 (less likely to occur) to 5 (more likely to occur). A high elevation in troponin, BNP, ferritin, CRP, and D-dimer prevails, with less lymphocytes and albumin alterations.

KD: Kawasaki disease; iKD: incomplete Kawasaki disease; MIS-C: multisystem inflammatory syndrome in children (MIS-C) temporally related to COVID-19; CRP: C-reactive protein. 
TABLE 2. Laboratory findings according to different publications ${ }^{13-15,20,21}$

\begin{tabular}{|c|c|c|c|c|c|c|c|}
\hline & \multicolumn{6}{|c|}{ Publications (countries where patients were included) } \\
\hline & & $\begin{array}{c}\text { Belhadjer et al. } \\
\text { (France and } \\
\text { Switzerland) } \\
n=35\end{array}$ & $\begin{array}{l}\text { Verdoni et } \\
\text { al. (Italy) } \\
n=10\end{array}$ & $\begin{array}{c}\text { González- } \\
\text { Dambrauskas et } \\
\text { al. (Italy, Spain, } \\
\text { Chile, Colombia, } \\
\text { USA)" } \\
n=17\end{array}$ & $\begin{array}{c}\begin{array}{c}\text { Duffort et al. } \\
\text { (USA) }\end{array} \\
n=99\end{array}$ & $\begin{array}{l}\begin{array}{c}\text { Feldstein et al. } \\
\text { (USA) }\end{array} \\
n=186\end{array}$ & $\begin{array}{c}\text { Davies et al. } \\
\text { (United } \\
\text { Kingdom) } \\
n=78\end{array}$ \\
\hline \multirow{10}{*}{ 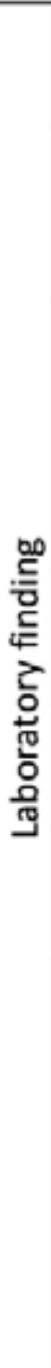 } & $\begin{array}{l}\text { Neutrophils } \\
\text { Highest value } \times 10^{1} / \mathrm{mL} \text { (IQR) } \\
\%=\text { patients with neutrophilia } \\
\text { in the series }\end{array}$ & $\begin{array}{c}13 \\
(8-19)\end{array}$ & $84.5 \%$ & NR & $0 \%$ & $68 \%$ & NR \\
\hline & \begin{tabular}{|l|} 
Lymphocytes \\
Highest value $\times 10^{3} / \mathrm{mL}$ (IQR) [SD] \\
$\%=$ patients with lymphopenia \\
in the series
\end{tabular} & NR & $\begin{array}{l}0.86 \\
{[0.4]}\end{array}$ & $47 \%$ & $66 \%$ & $80 \%$ & $\begin{array}{c}0.80 \\
(0.41-1.1)\end{array}$ \\
\hline & \begin{tabular}{|l|} 
Platelets \\
Highest value $\times 10^{3} / \mathrm{mL}$ (IQR) \\
$\%=$ patients with \\
thrombocytopenia in the series
\end{tabular} & NR & 130 & NR & $\begin{array}{c}155 \\
(105-233) \\
11 \%\end{array}$ & $\begin{array}{c}133 \\
(88-235) \\
55 \%\end{array}$ & $\begin{array}{c}151 \\
(93-208)\end{array}$ \\
\hline & \begin{tabular}{|l|} 
CRP \\
Highest value in $\mathrm{mg} / \mathrm{dL}$ (IQR) [SD] \\
$\%=$ patients above the cutoff \\
point
\end{tabular} & $\begin{array}{c}24.1 \\
(15.0-31.1)\end{array}$ & $\begin{array}{c}25 \\
{[15.3]}\end{array}$ & $76 \%$ & $\begin{array}{c}21.9 \\
(15.0-30.0) \\
100 \%\end{array}$ & $\begin{array}{c}17.8 \\
(12.8-25.9) \\
91 \%\end{array}$ & $\begin{array}{c}25.1 \\
(19.2-30.7)\end{array}$ \\
\hline & \begin{tabular}{|l|} 
Ferritin \\
Highest value in ng/dL (IQR) [SD] \\
$\%=$ patients above the cutoff \\
point
\end{tabular} & NR & $\begin{array}{c}1176 \\
{[1032]}\end{array}$ & $41 \%$ & $\begin{array}{c}522 \\
(305-820) \\
75 \%\end{array}$ & $\begin{array}{c}639 \\
(332.7-1178.2) \\
61 \%\end{array}$ & $\begin{array}{c}958 \\
(516-1554)\end{array}$ \\
\hline & $\begin{array}{l}\text { Procalcitonin } \\
\text { Highest value in ng/dL (IQR) } \\
\%=\text { patients above the cutoff } \\
\text { point }\end{array}$ & $\begin{array}{c}36 \\
(8-99)\end{array}$ & NR & $35 \%$ & $\begin{array}{c}6.2 \\
(2.2-19.7) \\
92 \%\end{array}$ & NR & NR \\
\hline & \begin{tabular}{|l|} 
Troponin \\
Highest value in ng/L (IQR) [SD] \\
$\%=$ patients above the cutoff \\
point
\end{tabular} & $\begin{array}{c}347 \\
(186-1267)\end{array}$ & $\begin{array}{c}1004 \\
{[1862]}\end{array}$ & $25 \%$ & $71 \%$ & $50 \%$ & $\begin{array}{c}167 \\
(41-1112)\end{array}$ \\
\hline & \begin{tabular}{|l|} 
Pro-BNP \\
Highest value in $\mathrm{pg} / \mathrm{mL}$ (IQR) [SD] \\
$\%=$ patients above the cutoff \\
point
\end{tabular} & $\begin{array}{c}5743 \\
(2648-11909)\end{array}$ & $\begin{array}{l}1255 \\
{[829]}\end{array}$ & NR & $90 \%$ & $\begin{array}{c}1194.7 \\
(390.8-4833) \\
73 \%\end{array}$ & NR \\
\hline & \begin{tabular}{|l|} 
D-dimer \\
Highest value in $\mathrm{ng} / \mathrm{mL}$ (IQR) [SD] \\
$\%=$ patients above the cutoff \\
point
\end{tabular} & $\begin{array}{c}5284 \\
(4069-9095)\end{array}$ & $\begin{array}{c}3798 \\
{[1318]}\end{array}$ & $41 \%$ & $\begin{array}{c}2400 \\
(1200-3700) \\
91 \%\end{array}$ & $\begin{array}{c}4090 \\
(2240-8404.5) \\
67 \%\end{array}$ & $\begin{array}{c}3750 \\
(2106-6958)\end{array}$ \\
\hline & $\begin{array}{l}\text { Fibrinogen } \\
\text { Highest value in mg/dL (IQR) [SD] } \\
\%=\text { patients above the cutoff } \\
\text { point }\end{array}$ & 0 & $\begin{array}{c}621 \\
{[182]}\end{array}$ & NR & $\begin{array}{c}624 \\
(506-764) \\
86 \%\end{array}$ & $80 \%$ & NR \\
\hline
\end{tabular}

IQR: interquartile range; SD: standard deviation; CRP: C-reactive protein; pro-BNP: pro B-type natriuretic peptide. Data expressed as per the data reported in the publications: $\%(\mathrm{n} / \mathrm{N})$, according to the number of patients above the cutoff point. Cutoff points:

${ }^{a}$ Cutoff points: lymphopenia < $1000\left(1 \times 10^{3}\right) / \mathrm{mL}$; CRP: > $0.2 \mathrm{mg} / \mathrm{L}$; ferritin: > $200 \mathrm{ng} / \mathrm{mL}$; procalcitonin: $2 \mathrm{ng} / \mathrm{dL}$;

D-dimer: $>500 \mathrm{ng} / \mathrm{mL}$; ferritin: > $300 \mathrm{ng} / \mathrm{mL}$.

${ }^{\mathrm{b}}$ Cutoff points in the study by Duffort: lymphopenia $<2.5 \%(<1$ month old $) /<4.0 \% \quad(1-12$ months old $) /<3.0 \%$ $(1-2$ years old $) /<2.0 \%$ ( $2-4$ years old) $/<1.5 \%$ ( $4-10$ years old $) /<1.2 \%$ ( $10-16$ years old $) /<1.0 \%$ ( $>16$ years old); thrombocytopenia: < 80 000; CRP (C-reactive protein): $\geq 3 \mathrm{mg} / \mathrm{dL}$, ferritin: $>300 \mathrm{ng} / \mathrm{mL}$; procalcitonin: $0.5 \mathrm{ng} / \mathrm{dL}$; pro-BNP: > $1121 \mathrm{pg} / \mathrm{mL}(1$ month-1 year old $) / 675 \mathrm{pg} / \mathrm{mL}(1-2$ years old $) / 391 \mathrm{pg} / \mathrm{mL}(2-14$ years old $) / 363 \mathrm{pg} / \mathrm{mL}$ (> 14 years old); D-dimer: $>550 \mathrm{ng} / \mathrm{mL}$; fibrinogen: $>400 \mathrm{mg} / \mathrm{dL}$.

${ }^{c}$ Cutoff points in the study by Feldstein: thrombocytopenia < 150 000; CRP (C-reactive protein): $\geq 3 \mathrm{mg} / \mathrm{dL}$; ferritin: $>500 \mathrm{ng} / \mathrm{mL}$; pro-BNP: > $400 \mathrm{pg} / \mathrm{mL}$; D-dimer: $>3000 \mathrm{ng} / \mathrm{mL}$; fibrinogen: $>400 \mathrm{mg} / \mathrm{dL}$. 
COVID-19 admitted to the pediatric intensive care unit (PICU) had a median age of 4 years. ${ }^{18}$ The initial clinical signs include high and persistent fever for $>3$ days, maculopapular skin lesions similar to KD, gastrointestinal symptoms (nausea, vomiting, diarrhea or abdominal pain) and myocardial involvement. ${ }^{5,10-22}$ If shock is present, it is not possible to clinically differentiate it from SSh. ${ }^{23-26,28,29}$ Heart involvement, which is present in a high percentage of patients, includes myocardial dysfunction, coronary artery aneurysms, pericarditis, arrhythmias, refractory shock and/or elevated cardiac biomarkers, including troponin I or brain natriuretic peptide, even in the absence of major cardiac involvement. ${ }^{10,19,22,48-50}$

The CAKE study reported a lower frequency of cardiac involvement than other European studies, ${ }^{18}$ which probably pointed out phenotypes of the same disease. Duffort et al., ${ }^{19}$ and Franco Díaz (personal communication about patients with MIS-C in Chile) noted that the presence of clinical and laboratory signs varied depending on age. Skin involvement and similar signs are believed to prevail among patients aged $0-5$ years, whereas myocarditis and neurological symptoms are common among those aged $13-20$ years $^{19}$ (Figure 2).

The most common laboratory findings are leukocytosis, neutrophilia, lymphopenia, anemia, and thrombocytopenia. ${ }^{2}$ Inflammatory biomarkers are high (C-reactive protein [CRP], procalcitonin, serum ferritin, interleukin-1, and interleukin-6) (Table 2). As in the case of sepsis, a simultaneous increase in CRP and ferritin is associated with other phenotypes which show a poorer course. ${ }^{5,10-22,24-27,51}$

In MIS-C, there is a procoagulant state evidenced by different biochemical alterations. Although COVID-19-induced coagulopathy shares features with other types of coagulopathy, it may be a new variation. ${ }^{52}$ In spite of a high $\mathrm{D}$-dimer value, at baseline, fibrinogen levels are also high, which suggests a predominantly inflammatory response (endotheliitis) rather than a consumptive coagulopathy. ${ }^{20,21,52}$ Given that the level of serum hyaluronic acid, a key component in glycocalyx, is higher during childhood, the endothelium may be more protected, with a lower probability of a hypercoagulable state. ${ }^{53,54}$

If MIS-C suspicion is low, it is suggested to order white blood cell count with blood differential test, in addition to platelet count, CRP or erythrocyte sedimentation rate. If MIS-C suspicion is strong or it is confirmed, it is suggested to order more extensive tests: ferritin, procalcitonin, troponin, D-dimer, coagulation tests, transaminases, and lactate dehydrogenase. ${ }^{24-27}$

The onset of cases 4-6 weeks after the regional pandemic peak and the report of patients with negative rtPCR and positive serology (immunoglobulin G [IgG] or immunoglobulin $\mathrm{M}[\mathrm{IgM}]$ for severe acute respiratory syndrome coronavirus 2 [SARS-CoV-2]) support the hypothesis of a post-infection inflammatory process related to COVID-19. ${ }^{10-22}$

Given that, signs and symptoms are nonspecific and presentation varies, in the context of a pandemic and in accordance with local epidemiological guidelines, if a patient's condition is suspicious, physicians should think: "Could this be MIS-C?"33 In suggestive cases with normal lab tests, patients should receive specific discharge instructions and follow-up in the following 24-72 hours, either in-person or through telemedicine. ${ }^{25}$ The Paediatric Sepsis Six approach proposed by the United Kingdom Paediatric Sepsis Group ${ }^{55}$ has been modified for the initial approach of MIS-C (Figure 3).

\section{RESUSCITATION BUNDLE \\ General aspects}

As with SSh, resuscitation is targeted at correcting hemodynamic and metabolic alterations. ${ }^{30,31,56}$ Local resources should be considered beforehand so that recommendations do not fail because of suggesting unavailable elements (e.g., lab tests, monitoring methods or treatment options) (Figure 4). ${ }^{57}$

\section{Monitoring}

A lack of invasive hemodynamic monitoring is no justification for a delayed management. Non-invasive monitoring includes continuous electrocardiogram and the measurement of respiratory rate (RR), heart rate (HR), blood pressure (BP), shock index (SI), oxygen saturation $\left(\mathrm{SatO}_{2}\right)$, urine flow (UF), rectal or axillary temperature. ${ }^{30,31}$ If available, it is advisable to use advanced hemodynamic, in addition to clinical, outcome measures, as guidance for resuscitation (continuous invasive $\mathrm{BP}$, central venous pressure [CVP], and $\mathrm{SatO}_{2}$ in the superior vena cava $\left.\left[\mathrm{SatO}_{2 \mathrm{svc}}\right]\right)$. The target $\mathrm{SatO}_{2 \mathrm{svc}}$ is $>70 \%$; the value obtained for the inferior vena cava $\left(\mathrm{SatO}_{2 \mathrm{ivc}}\right)$ or the right atrium $\left(\mathrm{SatO}_{2 \mathrm{ra}}\right)$ is also valid. ${ }^{24-27,30,31,39,58,59}$ Although there is no evidence recommending the measurement of tissue/abdominal perfusion pressure (TPP/APP), some experts have pointed 
out a mean BP (MBP) between the $5^{\text {th }}$ and the $50^{\text {th }}$ percentile for age, while others suggested a MBP over the $50^{\text {th }}$ percentile. ${ }^{24,27}$ If mental status, perfusion, diuresis, and lactate improve, a lower BP may be tolerated. ${ }^{24,60}$ At the Emergency
Department, it may be practical to use the SI (HR/systolic BP [SBP]), thus reducing HR and increasing SBP. ${ }^{61,62}$

It is worth performing an echocardiogram to monitor myocardial function because of the

\section{MIS-C Six (Sepsis)}

\section{WEAR PERSONAL PROTECTIVE EQUIPMENT}

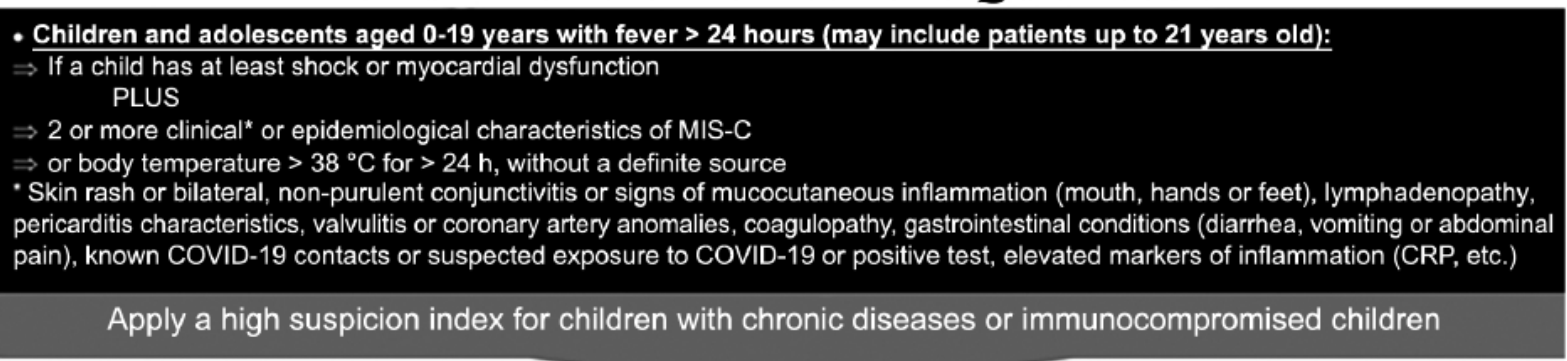

\section{THINK:}

Could this child have MIS-C? (check case definition)*

Request a consultation with an experienced pediatrician or pediatric emergency physician or pediatric intensivist Signature

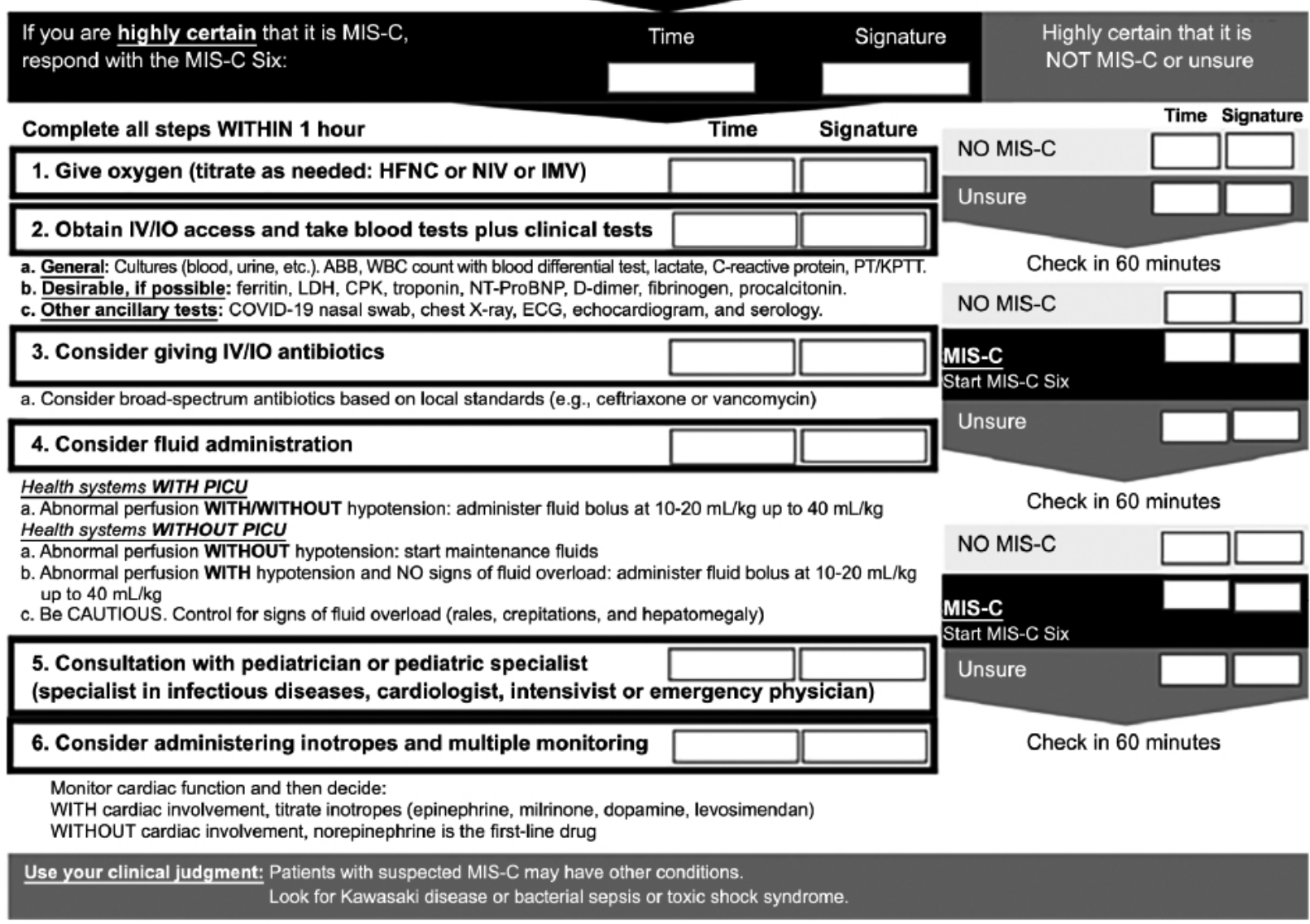

Translated and modified by the authors from Tong J, Plunkett A, Daniels R. G218(P) The Paediatric Sepsis 6 Initiative. Arch Dis Child. 2014;99(S1):A93.

IV: intravenous; IO: intraosseous; ECG: electrocardiogram. 
potential heart dysfunction caused by pulmonary hypertension (in relation to acute respiratory distress syndrome [ARDS], invasive mechanical ventilation [IMV] or pulmonary thromboembolism), myocarditis, and the possibility of coronary artery aneurysms (Z-score adjusted for body surface $>2.5$ ). An echocardiogram also allows to assess hypovolemia by observing if the inferior vena cava has minimum diameter variations throughout the breathing cycle. This allows to reverse shock more rapidly, with a lower fluid overload, a shorter length of stay, and a lower mortality rate compared to those who do not undergo an echocardiogram. ${ }^{64}$ The SSC suggests using lactate level trends rather than the baseline lactate level as a supplement to clinical examination. ${ }^{24}$

\section{Goals}

Goals are the same as those described for SSh: obtaining a patent airway, with adequate oxygenation and ventilation; normalizing HR for age, distal and central pulses, capillary refill, skin temperature, and the sensorium; and optimizing urine flow. ${ }^{30}$ Achieving these goals using stepwise treatments has reduced pediatric SSh mortality by $40 \% .{ }^{37}$

\section{Treatment}

a. Oxygen therapy: Supplemental oxygen $\left(\mathrm{O}_{2}\right)$ administration should meet the requirement levels based on hypoxemia and work of breathing. ${ }^{24-27}$ Given the risk of viral aerosol particles, strict personal protection measures should be followed and, if available, isolation rooms should be used. It is suggested to start with a low-flow nasal cannula if oxygen saturation $\left(\mathrm{SpO}_{2}\right)$ is $<90 \%$ and then escalate, as needed, to a high-flow nasal cannula (HFNC), ventilation with non-invasive positive pressure (NIPPV), continuous positive airway pressure (C-PAP) or bilevel positive airway pressure (BiPAP), and then IMV. ${ }^{27,66,67}$ Both hypoxemia and hyperoxia should be prevented. ${ }^{68}$

b. Fluids: The recommendations about vascular accesses are the same as for SSh. ${ }^{24-27,30,33}$ Patients with MIS-C may develop hypovolemia due to gastrointestinal losses before consultation, and

FIGURE 4. Levels of care, resources, and potential management (modified and translated from the original) ${ }^{55}$

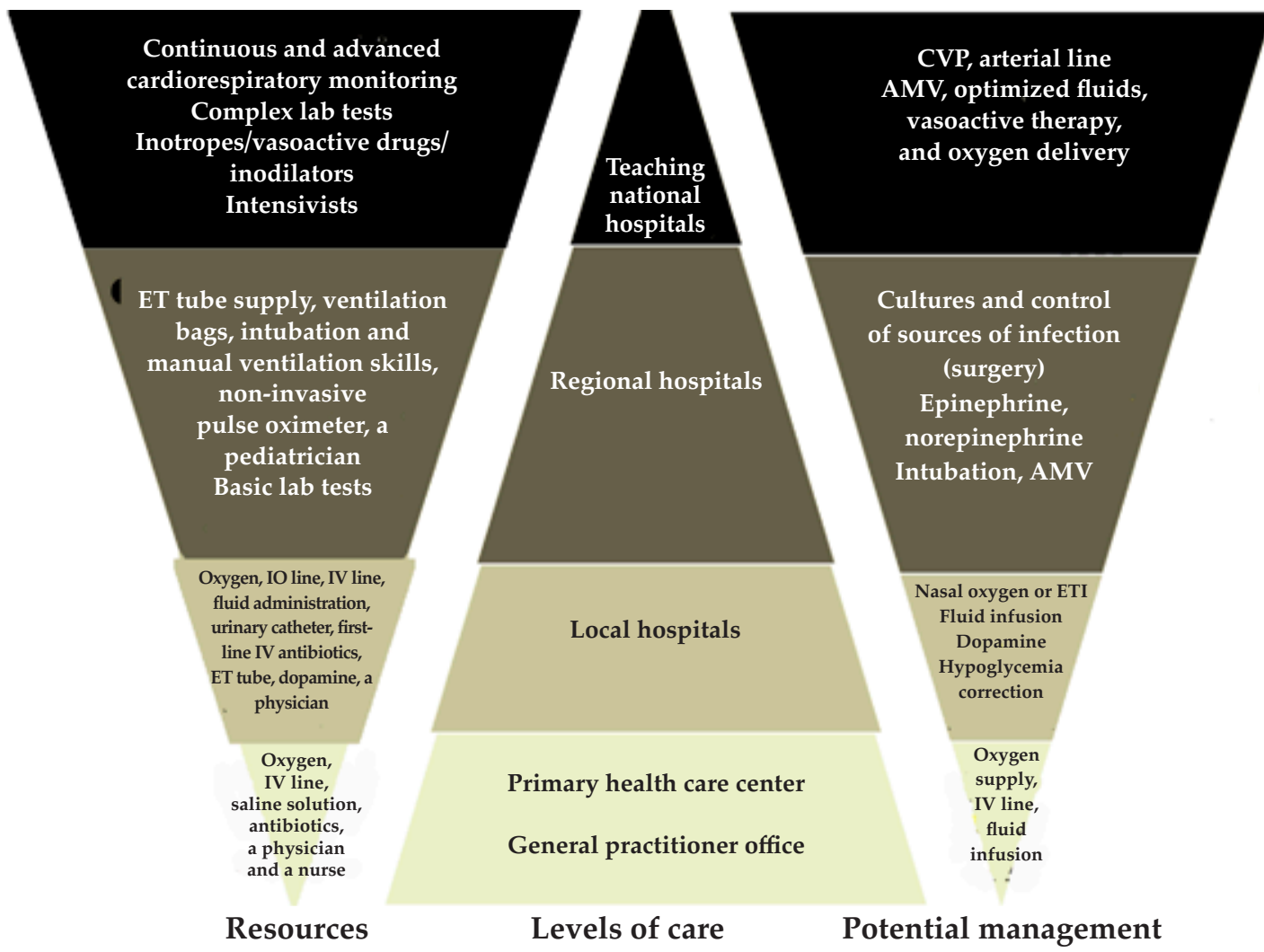

IV: intravenous; IO: intraosseous; ET: endotracheal; CVP: central venous pressure; AMV: assisted mechanical ventilation. 
they also frequently have heart dysfunction. The fluid administration strategy should be "adapted" to each patient and available resources: ${ }^{24,27}$

b.1. In health care systems where a PICU is available (with staff and equipment for an advanced airway management and vasoactive drug administration), balanced crystalloid solutions (Ringer's lactate) up to $40-60 \mathrm{~mL} / \mathrm{kg}$ (10-20 $\mathrm{mL} / \mathrm{kg}$ per bolus) should be given in the first hour, then titrated based on cardiac output clinical markers and stopped if fluid overload signs appear. ${ }^{24,27}$

b.2. If there is no PICU available and the patient has arterial hypotension, any available crystalloid solution (balanced or unbalanced) should be given up to $40 \mathrm{~mL} / \mathrm{kg}$ as a bolus (10-20 mL/ kg per bolus) in the first hour, then titrated based on cardiac output clinical markers and stopped if fluid overload signs appear. ${ }^{24,27}$

b.3. If there is no PICU available and the patient does not have arterial hypotension (compensated shock), maintenance fluids should be given, but avoiding bolus administration because it would worsen the outcomes. ${ }^{24,27}$ Some CPGs suggest the administration of fluids over 15 minutes, but there is now more evidence of the risk of this type of administration and, in practice, it is difficult to perform. ${ }^{69,70}$ Therefore, a goal close to 30 minutes may be more reasonable. ${ }^{30}$

c. Vasoactive drugs: In the absence of fluid response or in the presence of cardiogenic shock, vasoactive drugs should be infused through a peripheral venous access (PVA) (diluted), an intraosseous access or a central venous catheter (CVC). ${ }^{24-27,30}$ The most common MIS-C hemodynamic pattern is warm shock; however, contractile dysfunction is sometimes prevalent. Therefore, norepinephrine or epinephrine are proposed for the initial management based on the patient's hemodynamic profile. Dopamine, milrinone, levosimendan or vasopressin use has also been reported. ${ }^{10-22,24-27,30}$

d. Antibiotic therapy: Although MIS-C is a viral condition, in practice, it is very difficult to distinguish among MIS-C, SSh and TSS. At baseline, one or more empiric antibiotics should be administered to cover every probable pathogen (especially, staphylococci and streptococci) and then they should be tailored once the microorganism has been identified. ${ }^{24}$ Antibiotics should be administered as soon as possible, ideally in the first hour. ${ }^{24,27}$ It is important to perform a blood culture first, although this should not delay antibiotic administration. ${ }^{24,27}$ Sources of infection should be treated as soon as possible. ${ }^{24,27}$

e. Antiviral therapy: There is not enough evidence to recommend drug therapies in pediatric patients with SARS-CoV-2. Their use should be agreed upon by a multidisciplinary team. ${ }^{71}$

\section{STABILIZATION BUNDLE} (generally, after 60 minutes)

An inadequate response to the initial resuscitation measures requires invasive monitoring and PICU-relevant management and, although they exceed the objectives of this study, they deserve some considerations.

\section{Monitoring}

An initial monitoring should be completed and, if available, cardiac output should be measured. It is recommended to monitor for and treat compartment syndrome, pneumothorax, and/or arrhythmias due to potential myocarditis and to maintain glycemia $<180 \mathrm{mg} / \mathrm{dL} .{ }^{24}$

\section{Goals}

To continue with the same goals and achieve IMV optimization.

\section{Immunomodulatory therapy}

Given the little evidence available, it should be indicated based on a multidisciplinary approach..$^{25-27,71}$ Severe patients may receive it before completing MIS-C confirmation, unlike those without life-threatening involvement. ${ }^{27,71}$

The recommended intravenous immunoglobulin (IVIG) dose is $1-2 \mathrm{~g} / \mathrm{kg}$ for moderate to severe cases (myocardial involvement, persistent shock or high vasopressor doses), and sometimes two IVIG series are required. ${ }^{19,20,27,71}$ Low to moderate doses of methylprednisolone may be considered for all MIS-C patients; however, in the presence of shock or with high vasopressor doses, high pulse dosing may be indicated. ${ }^{27,71}$

In patients refractory to IVIG or corticosteroids, it is necessary to ask for the advice of personnel trained in using antiinflammatory biological therapies, like anakinra and tocilizumab. ${ }^{72}$ However, their use should be 
an exception because their indication and safety profile have not been established in pediatrics.

\section{Hematological considerations}

The rate of thrombosis observed in adults has not been reported in children, and it is recommended to document thrombosis in addition to providing a multidisciplinary management. ${ }^{10-22,73-76}$

a. At risk for venous thrombosis (VT) (with a $\mathrm{CVC}$ or indwelling peripheral catheter or severely ill with no hyperinflammatory state and with no risk for thrombosis), subcutaneous enoxaparin should be considered to achieve an anti-Xa factor level of 0.3-0.5 u/ mL:27

$<2$ months old: $0.75 \mathrm{mg} / \mathrm{kg} /$ dose every $12 \mathrm{~h}$

$>2$ months old: $0.5 \mathrm{mg} / \mathrm{kg} /$ dose every $12 \mathrm{~h}$

b. At high risk for VT (critically ill, hyperinflammatory state [CRP $>150 \mathrm{mg} / \mathrm{L}$, D-dimer $>1500 \mathrm{ng} / \mathrm{mL}$, IL-6 > $100 \mathrm{pg} / \mathrm{mL}$, ferritin $>500 \mathrm{ng} / \mathrm{mL}$ ], history of thromboembolic events, echocardiogram ejection fraction $<35 \%$ ), subcutaneous enoxaparin should be considered to achieve an anti-Xa factor level of $0.5-1 \mathrm{u} / \mathrm{mL}:{ }^{27}$

$<2$ months old: $1.5 \mathrm{mg} / \mathrm{kg} /$ dose every $12 \mathrm{~h}$

$>2$ months old: $1 \mathrm{mg} / \mathrm{kg} /$ dose every $12 \mathrm{~h}$

In patients with thrombocytosis (>450 $000 \mathrm{u} / \mathrm{L}$ ) or KD-like criteria, the suggestion is to give aspirin: $3-5 \mathrm{mg} / \mathrm{kg} /$ day (maximum: $81 \mathrm{mg} /$ day). ${ }^{72}$

Platelet transfusions are not advisable if the patient does not have active bleeding, even if they show an abnormal platelet count. Red blood cell transfusions are indicated for patients with a hemoglobin level $<7 \mathrm{~g} / \mathrm{dL}$ who are also hemodynamically stable. There is no clear recommendation about hemoglobin levels in hemodynamically unstable patients. ${ }^{24}$

\section{REFERRAL BUNDLE}

Health care teams specialized in critically-ill patients have reduced mortality and improved the clinical course of SSh; which highlights the importance of consulting trained staff for an adequate and timely treatment of MIS-C. ${ }^{77}$ A new modality, telemedicine (remote consultation using IT devices, such as mobile phones, computers, etc.) allows an expert to virtually and remotely see a patient. ${ }^{78-83}$

\section{OUTCOME MEASUREMENT BUNDLE}

The implementation of this bundle allows care process improvements..$^{41-43,84}$ The suggested items to be measured include bundle adherence, achievement of goals, barrier description, observed unwanted effects, and adherence to a timely antibiotic administration. ${ }^{30}$

\section{CONCLUSION}

MIS-C is a new form of COVID-19 in children and adolescents about which much remains to be studied. Its low prevalence does not rule out the need to establish its diagnosis and manage it because some patients with COVID-19 with few symptoms may worsen rapidly. Its clinical manifestations, lab test results, and natural course meet the criteria for viral sepsis with organ dysfunction; therefore, its initial management should be very similar.

\section{REFERENCES}

1. World Health Organization. Naming the coronavirus disease (COVID-19) and the virus that causes it. Geneva: WHO, Council for International Classification of Diseases (ICD). [Accessed on: July 10 ${ }^{\text {th }}, 2020$ ]. Available at: https: / / www.who.int/emergencies / diseases / novel-coronavirus-2019/technical-guidance/namingthe-coronavirus-disease-(covid-2019)-and-the-virus-thatcauses-it.

2. Hoang A, Chorath K, Moreira A, Evans M, et al. COVID-19 in 7780 pediatric patients: A systematic review. E Clinical Medicine. 2020. [Accessed on: July 10 ${ }^{\text {th }}, 2020$ ]. Available at: https: / / www.thelancet.com/pdfs/journals/eclinm/ PIIS2589-5370(20)30177-2.pdf.

3. Qiu H, Wu J, Hong L, Lou Y, et al. Clinical and epidemiological features of 36 children with coronavirus disease 2019 (COVID-19) in Zhejiang, China: an observational cohort study. Lancet Infect Dis. 2020; 20(6):68996.

4. ChaoJY, Derespina KR, HeroldBC, Goldman D, et al. Clinical Characteristics and Outcomes of Hospitalized and Critically Ill Children and Adolescents with Coronavirus Disease 2019 (COVID-19) at a Tertiary Care Medical Center in New York City. J Pediatr. 2020; 223:14-9.e2.

5. InternationalPediatric Association, UNICEF.Epidemiology, Spectrum, and Impact of COVID-19 on Children, Adolescents, and Pregnant Women. [Accessed on: July $\left.10^{\text {th }}, 2020\right]$ Available at: https://ipa-world.org/societyresources / code / images / x5f7u8p3T41e.pdf.

6. Dong Y,MoX,HuY,QiX,etal.Epidemiologicalcharacteristics of 2143 pediatric patients with 2019 coronavirus disease in China. Pediatrics. 2020, [Accessed on: July 10 ${ }^{\text {th }}, 2020$ ]. Available at: https:// pediatrics.aappublications.org/ content/ pediatrics / early / 2020/03/16/peds.2020-0702. full.pdf.

7. Centers for Disease Control and Prevention-CDCCOVID-19 Response Team. Coronavirus Disease 2019 in Children-United States, February 12-April 2, 2020.MMWR Morb Mortal Wkly Rep. 2020; 69(14):422-6.

8. Lu X, Zhang L, Du H, Zhang J, et al. SARS-CoV-2 Infection in Children. N Engl J Med. 2020; 382(17):1663-5.

9. Parri N, Lenge M, Buonsenso D. Coronavirus Infection in Pediatric Emergency Departments (CONFIDENCE) Research Group. Children with Covid-19 in Pediatric Emergency Departments in Italy. N Engl J Med. 2020; 383(2):187-90.

10. Riphagen S, Gomez X, Gonzalez-Martinez C, Wilkinson $\mathrm{N}$, et al. Hyperinflammatory shock in children during 
COVID-19 pandemic. Lancet. 2020; 395(10237):1607-8.

11. European Centre for Disease Prevention and Control (ECDC). Paediatric inflammatory multisystem syndrome and SARS-CoV-2 infection in children. May $15^{\text {th }}$, 2020. Stockholm. 2020. [Accessed on: July 10 ${ }^{\text {th }}, 2020$ ]. Available at:https:/ / www.ecdc.europa.eu/sites/default / files / documents / covid-19-risk-assessment-paediatricinflammatory-multisystem-syndrome-15-May-2020.pdf.

12. Centers for Disease Control and Prevention. Information for Healthcare Providers about Multisystem Inflammatory Syndrome in Children (MIS-C). [Accessed on: July $10^{\text {th }}$, 2020]. Available at: https://www.cdc.gov/mis-c/hcp/ index.html.

13. Belhadjer Z, MéotM, BajolleF, KhraicheD, etal. Acuteheart failure in multisystem inflammatory syndrome in children (MIS-C) in the context of global SARS-CoV-2 pandemic. Circulation. 2020. [Accessed on: July 10 $0^{\text {th }}, 2020$ ]. Available at: https: / / www.ahajournals.org/doi / pdf/10.1161/ CIRCULATIONAHA.120.048360.

14. Verdoni L, Mazza A, Gervasoni A, Martelli L, et al. An outbreak of severe Kawasaki-like disease at the Italian epicentre of the SARS-CoV-2 epidemic: an observational cohort study. Lancet. 2020; 39(10239):1771-8.

15. Centers for Disease Control and Prevention. Multisystem Inflammatory Syndrome in Children (MIS-C) associated with coronavirus disease 2019 (COVID-19). [Accessed on: July $\left.10^{\text {th }}, 2020\right]$. Available at: https: / / emergency.cdc.gov / han/2020/han00432.asp.

16. World Health Organization. Multisystem inflammatory syndrome in children and adolescents with COVID 19 Scientific brief. May $15^{\text {th }}, 2020$. [Accessed on: July $10^{\text {th }}$, 2020]. Available at: https://www.who.int/publicationsdetail/multisystem-inflammatory-syndrome-in-childrenand-adolescents-with-covid-19.

17. DeBiasi RL, Song X, Delaney M, Bell M, et al. Severe COVID-19 in Children and Young Adults in the Washington, DC Metropolitan Region. J Pediatr. 2020; 223:199-203.e1.

18. González-DambrauskasS, Vásquez-Hoyos P,Camporesi A, Díaz-Rubio F, et al. Pediatric Critical Care and COVID19. Pediatrics. 2020;e20201766.

19. Belot A, Antona D, Renolleau S, Javouhey E, et al. SARSCoV-2-related paediatric inflammatory multisystem syndrome, an epidemiological study, France, 1 march to 17 may 2020. Euro Surveill. 2020; 25(22):2001010.

20. Dufort EM, Koumans EH, Chow EJ, Rosenthal E, et al. Multisystem Inflammatory Syndrome in Children in New York State. N Engl J Med. 2020; NEJMoa2021756.

21. Feldstein LR, Rose EB, Horwitz SM, Collins J, et al. Multisystem Inflammatory Syndrome in U.S. Children and Adolescents. N Engl J Med. 2020; NEJMoa2021680.

22. Davies P, Evans C, Kanthimathinathan HK, Lillie J, et al. Intensive care admissions of children with paediatric inflammatory multisystem syndrome temporally associated with SARS-CoV-2 (PIMS-TS) in the UK: a multicentre observational study. Lancet Child Adolesc Health. 2020; S2352-4642(20)30215-7.

23. Singer M, Deutschman CS, Seymour CW, Shankar-Hari $\mathrm{M}$, et al. The Third International Consensus Definitions for Sepsis and Septic Shock (Sepsis-3). JAMA. 2016; 315 (8):80110.

24. Weiss SL, Peters MJ, Alhazzani W, Agus MS, et al. Surviving sepsis campaign international guidelines for the management of septic shock and sepsis-associated organ dysfunction in children. Intensive Care Med. 2020; 46(Suppl 1):10-67.

25. Hennon TR, Penque MD, Abdul-Aziz R, Alibrahim OS, et al. COVID-19 associated Multisystem Inflammatory
Syndrome in Children (MIS-C) guidelines; a Western New York approach. Progress Pediatr Cardiol.2020. [Accessed on: July $10^{\text {th }}$, 2020]. Available at: https:/ / www.ncbi.nlm.nih. gov/pmc/articles/PMC7244417/pdf/main.pdf.

26. Nakra NA, Blumberg DA, Herrera-Guerra A, Lakshminrusimha S. Multi-System Inflammatory Syndrome in Children (MIS-C) Following SARS-CoV-2 Infection: Review of Clinical Presentation, Hypothetical Pathogenesis, and Proposed Management. Children (Basel). 2020; 7(7):E69.

27. Kache S, Chisti MJ, Gumbo F, Mupere E, et al. COVID-19 PICU guidelines: for high- and limited-resource settings. Pediatr Res. 2020. [Accessed on: July 10 $0^{\text {th }}, 2020$ ]. Available at: https: / www.nature.com/articles/s41390-020-10539_reference.pdf.

28. Ministerio de Salud de Argentina. Definición de caso COVID-19. [Accessed on: July 10 ${ }^{\text {th }}, 2020$ ]. Available at: https: / / www.argentina.gob.ar/salud / coronavirusCOVID-19/definicion-de-caso.

29. Kohn Loncarica G, Fustiñana A, Jabornisky R. Recomendaciones para el manejo del shock séptico en niños durante la primera hora (primera parte). Arch Argent Pediatr. 2019; 117(1):e14-23.

30. Kohn Loncarica G, Fustiñana A, Jabornisky R. Recomendaciones para el manejo del shock séptico en niños durante la primera hora (segunda parte). Arch Argent Pediatr. 2019; 117(1):e24-33.

31. Davis AL, Carcillo JA, Aneja RK, Deymann AJ, et al. American College of Critical Care MedicineClinical Practice Parameters for Hemodynamic Support of Pediatric and Neonatal Septic Shock. Crit Care Med. 2017; 45(6):1061-93.

32. Wip C, Napolitano L. Bundles to prevent ventilatorassociated pneumonia: how valuable are they? Curr Opin Infect Dis. 2009; 22(2):159-66.

33. National Institute for Health and Care Excellence. Sepsis: Recognition, Assessment and Early Management. 2016. [Accessed on: July 10 $10^{\text {th }}, 2020$ ]. Available at: https: / / www.nice.org.uk/guidance/ng51/resources / sepsis-recognition-diagnosisand-early-managementpdf-1837508256709.

34. Peake SL, Delaney A, Bailey M, Bellomo R, et al. Goaldirected resuscitation for patients with early septic shock. N Engl J Med. 2014; 371(16):1496-506.

35. Yealy DM, Kellum JA, Huang DT, Barnato A, et al. A randomized trial of protocol-based care for early septic shock. N Engl J Med. 2014; 370(18):1683-93.

36. Mouncey PR, Osborn TM, Power GS, Harrison DA, et al. Trial of early, goal directed resuscitation for septic shock. N Engl J Med 2015; 372(14):1301-11.

37. Han YY, Carcillo JA, Dragotta MA, Bills DM, et al. Early reversal of pediatric-neonatal septic shock by community physicians is associated with improved outcome. Pediatrics. 2003; 112(4):793-9.

38. Ventura AM, Shieh HH, Bousso A, Góes P, et al. Doubleblind prospective randomized controlled trial of dopamine versus epinephrine as first-line vasoactive drugs in pediatric septic shock. Crit Care Med. 2015; 43(11):2292-302.

39. De Oliveira CF, De Oliveira DS, Gottschald AF, Moura J, et al. ACCM/PALS haemodynamic support guidelines for paediatric septic shock: An outcomes comparison with and without monitoring central venous oxygen saturation. Intensive Care Med. 2008; 34(6):1065-75.

40. Balamuth F, Weiss SL, Fitzgerald JC, Hayes K, et al. Protocolized Treatment Is Associated With Decreased Organ Dysfunction in Pediatric Severe Sepsis. Pediatr Crit Care Med. 2016; 17(9):817-22.

41. Cruz AT, Perry AM, Williams EA, Graf J, et al. Implementation of goal-directed therapy for children with 
suspected sepsis in the emergency department. Pediatrics. 2011; 127(3):e758-66.

42. Larsen GY, Mecham N, Greenberg R. An emergency department septic shock protocol and care guideline for children initiated at triage. Pediatrics 2011; 127(6):e1585-92.

43. Paul R, Neuman M, Monuteaux MC, Melendez E. Adherence to PALS Sepsis Guidelines and Hospital Length of Stay. Pediatrics 2012; 130(2):e273-80.

44. Royal College of Paediatrics and Child Health. Guidance: paediatric multisystem inflammatory syndrome temporally associated with COVID-19 (PIMS). 2020 [Accessed on: July $\left.10^{\text {th }}, 2020\right]$. Available at: https: / / www.rcpch.ac.uk/ sites / default / files / 2020-05 / COVID-19-Paediatricmultisystem- $\% 20$ inflammatory $\% 20$ syndrome-20200501. pdf.

45. Angus D, Seymour C, Coopersmith CM, Deutschman C, et al. Framework for the Development and Interpretation of Different Sepsis Definitions and Clinical Criteria. Crit Care Med. 2016; 44(3):e113-21.

46. Vincent JL, Opal SM, Marshall JC, Tracey K. Sepsis definitions: time for change. Lancet. 2013; 381(9868):774-5.

47. Seymour CW, Liu VX, Iwashyna TJ, Brunkhorst F, et al. Assessment of Clinical Criteria for Sepsis: For the Third International Consensus Definitions for Sepsis and Septic Shock (Sepsis-3). JAMA. 2016; 315(8):762-74.

48. Tan W, Aboulhosn J. The cardiovascular burden of coronavirus disease 2019 (COVID-19) with a focus on congenital heart disease. Int J Cardiol. 2020; 309:70-7.

49. Tunuguntla H, Jeewa A, Denfield SW. Acute Myocarditis and Pericarditis in Children. Pediatr Rev. 2019; 40(1):14-25.

50. Ramcharan T, Nolan O, Lai CY, Prabhu N, et al. Paediatric Inflammatory Multisystem Syndrome: Temporally Associated with SARS-CoV-2 (PIMS-TS): CardiacFeatures, Management and Short-Term Outcomes at a UK Tertiary Paediatric Hospital. Pediatr Cardiol. 2020; 1-11.

51. Horvat C, Bell J, KantawalaS, Ku A, et al. C-Reactive protein and Ferritin are Associated with Organ Dysfunction and Mortality in Hospitalized Children. Clin Pediatr (Phila). 2019; 58(7):752-60.

52. Iba T, Levy JH, Connors JM, Warketin T, et al. The unique characteristics of COVID-19 coagulopathy. Crit Care. 2020; 24(1):360.

53. TrivediP, Cheeseman P, Mowat AP. Serumhyaluronic acid in healthy infants and children and its value as a marker of progressive hepatobiliary disease starting in infancy. Clin Chim Acta. 1993; 215(1):29-39.

54. Fernández-Sarmiento J, Salazar-Peláez LM, Carcillo JA. The Endothelial Glycocalyx: A Fundamental Determinant of Vascular Permeability in Sepsis. Pediatr Crit Care Med. 2020; 21(5):e291-300.

55. Tong J, Plunkett A, Daniels R. G218(P)The Paediatric sepsis 6 initiative. Arch Dis Child. 2014; 99(Suppl 1):A93.

56. Jabornisky R, Mansur A. Shock. In Sociedad Argentina de Pediatría. PRONAP 2013; 1:81-109.

57. Kissoon N. Sepsis guideline implementation: benefits, pitfalls and possible solutions. Crit Care. 2014; 18(2):207.

58. CarcilloJA, Han K, Lin J, Orr R. Goal-Directed Management of Pediatric Shock in the Emergency Department. Clin Pediatr Emerg Med. 2007; 8(3):165-75.

59. Han YY, Carcillo JA, Espinosa V, Kissoon N, et al. Quality improvement analysis of the global pediatric sepsis initiative registry. Pediatr Crit Care Med. 2014; 15(4 Suppl):15-6.

60. Haque IU, Zaritsky AL. Analysis of the evidence for the lower limit of systolic and mean arterial pressure in children. Pediatr Crit Care Med. 2007; 8(2):138-44.

61. Yasaka Y, Khemani RG, Markovitz BP. Is Shock index associated with outcome in children with sepsis/septic shock? Pediatr Crit Care Med. 2013; 14(8):e372-9.

62. Berger T, Green J, Horeczko T, Hagar Y, et al. Shock index and early recognition of sepsis in the emergency department: pilot study. West J Emerg Med. 2013; 14(2):168-74.

63. AryaB,KersteinD, LeuCS, HayesD, etal.Echocardiographic assessment of right atrial pressure in a pediatric and young adult population. Pediatr Cardiol. 2016; 37(3):558-67.

64. El-Nawawy AA, Abdelmohsen AM, Hassouna HM. Role of echocardiography in reducing shock reversal time in pediatric septic shock: a randomized controlled trial. J Pediatr (Rio J). 2018; 94(1):31-9.

65. Sociedad Argentina de Pediatría; Sociedad Argentina de Cardiología. Enfermedad de Kawasaki: Consenso interdisciplinario e intersociedades (guía práctica clínica). Versión abreviada. Arch Argent Pediatr. 2016; 114(4):385-90.

66. World Health Organization. Oxygen therapy for children: a manual for health workers. Geneva: WHO; 2016. [Accessed on: July $\left.10^{\text {th }}, 2020\right]$. Available at: http://www.who.int/ maternal_child_adolescent/documents / child-oxygentherapy/en/.

67. World Health Organization. Clinical management of severe acute respiratory infection when novel coronavirus (2019-nCoV) infection is suspected. 2020. [Accessed on: July $10^{\text {th }}, 2020$ ]. Available at: https: / / apps.who.int/iris/ handle/10665/330893.

68. Cam BV, Tuan DT, Fonsmark L, Poulsen A, et al. Randomized comparison of oxygen mask treatment vs nasal continuous positive airway pressure in dengue shock syndrome with acute respiratory failure. J Trop Pediatr. 2002; 48(6):335-9.

69. Kohn-Loncarica GA, Fustiñana AL, Jabornisky RM, Pavlicich S, et al. How Are Clinicians Treating Children With Sepsis in Emergency Departments in Latin America?: An International Multicenter Survey. Pediatr Emerg Care. 2019. [Accessed on: July 10 $\left.{ }^{\text {th }}, 2020\right]$. Available at: https: / / journals.lww.com/pec-online/Abstract/9000/How_Are_ Clinicians_Treating_Children_With_Sepsis.98136.aspx.

70. Sankar J, Ismail J, Sankar MJ, Suresh CP, et al. Fluid Bolus Over 15-20 Versus 5-10 Minutes Each in the First Hour of Resuscitation in Children WithSepticShock: A Randomized Controlled Trial. Pediatr Crit Care Med. 2017; 18(10):e43545.

71. Calvo C, García López-Hortelano M, De Carlos Vicente JC, Vázquez Martínez JL, et al. Recomendaciones sobre el manejo clínico de la infección por el «nuevo coronavirus» SARS-CoV2. An Pediatr (Barc). 2020; 92(4):241.e1-11.

72. American College of Rheumatology. Clinical Guidance for Pediatric Patients with multisystem inflammatory syndrome in children (MIS-C) associated withSARS-CoV-2 and hyperinflammation in covid-19. 2020. [Accessed on: July $\left.10^{\text {th }}, 2020\right]$. Available at: https: / / www.rheumatology. org / Portals / 0 / Files / ACR-COVID-19-Clinical-GuidanceSummary-MIS-C-Hyperinflammation.pdf.

73. Xie Y, Wang X, Yang P, Zhang S. COVID-19 Complicated by Acute Pulmonary Embolism. Radiology Cardiothoracic Imaging. 2020; 2(2):e200067.

74. Tang N, Li D, Wang X, Sun Z. Abnormal coagulation parameters are associated with poor prognosis in patients with novel coronavirus pneumonia. J Thromb Haemost. 2020; 18(4):844-7.

75. LiT, LuH, Zhang W. Clinical observation and management of COVID-19 patients. Emerg Microbes Infect. 2020; 9(1):68790.

76. Klok FA, Kruip MJHA, Van der Meer NJM, Arbous MS, et al. Incidence of thrombotic complications in critically ill ICU patients with COVID-19. Thromb Res. 2020; 191:145-7.

77. Ninis N, Phillips C, Bailey L, Pollock JI, et al. The role of healthcare delivery in the outcome of meningococcal disease 
in children: case-control study of fatal and non-fatal cases. BMJ. 2005; 330(7506):1475.

78. Rosenthal JL, Kissee JL, Marcin JP. To See or Not to See: Telemedicine's Impact on Triage Outcomes. Pediatr Critl Care Med. 2017; 18(11):1081-3.

79. Harvey JB, Yeager BE, Cramer C, Wheeler D, et al. The Impact of Telemedicine on Pediatric Critical Care Triage. Pediatr Crit Care Med. 2017; 18(11):e555-60.

80. Dharmar M, Romano PS, Kuppermann N, Nesbitt T, et al. Impact of critical care telemedicine consultations on children in rural emergency departments. Crit Care Med. 2013; 41(10):2388-95.

81. Gattu R, Teshome G, Lichenstein R. Telemedicine applications for the pediatric emergency medicine: A review of the current literature. Pediatr Emerg Care. 2016; 32(2):123-30.

82. Pannu J, Sanghavi D, Sheley T, Schroeder D, et al. Impact of telemedicine monitoring of community ICUs on interhospital transfers. Crit Care Med. 2017; 45(8):1344-51.

83. Pujales G. Organización de un sistema de transporte de pacientes críticos. Mesa Redonda: Abordaje del niño y sus familias en situación de desastres. $8 .{ }^{\circ}$ Congreso Argentino deEmergencias y Cuidados Críticos en Pediatría. 26-28 abril de 2017. Buenos Aires: Sociedad Argentina de Pediatría; 2017.

84. Fernández-Sarmiento J, Carcillo JA, Salinas CM, Galvis E, et al. Effect of a sepsis educational intervention on hospital stay. Pediatr Crit Care Med. 2018; 19(6):e321-8. 